\title{
IS ANCESTOR VENERATION COMPATIBLE WITH THE BIBLICAL FAITH?
}

\author{
Klaus Nürnberger \\ School of Religion and Theology \\ University of KwaZulu-Natal
}

\begin{abstract}
As part of a research project on ancestor veneration in the church this essay explores the stance of biblical witness on a few fundamental issues: (a) How important is past history for the biblical faith? (b) What is the role of the prime ancestors of Israel in the biblical faith? (c) Can the deceased mediate between humans and God? (d) Should the deceased exercise authority over the living? (e) Does respect, gratitude and love for one's forebears imply dependency on them as superiors? (f) Does the exclusiveness of the biblical faith imply intolerance and religious imperialism? (g) Can African insights and metaphors be used to express the message of the gospel?
\end{abstract}

Keywords: Ancestor Veneration, Abraham, Isaac and Jacob, Exclusiveness, Ancestors as Mediators, Ancestral Authority, Enculturation

\section{The Task}

This essay is part of a greater research project that explores the appropriateness of ancestor veneration in the church of Christ. The project as a whole listens to African Traditional Religion, the Bible, the Reformation, modernity and post-modernity. ${ }^{1}$ In a companion essay I described the phenomenon within its religious and social context and argued that the classical Christian gospel failed to respond to African spiritual needs. ${ }^{2}$ In this essay I explore what the Bible says about this issue.

The intricacies of biblical interpretation are not part of the present agenda. Therefore I will frequently refer the reader to my books on hermeneutics and biblical theology. ${ }^{3}$ Suffice it to say that the Word of God is, and always has been, God's redemptive response to human needs and predicaments. Human needs and their interpretations change from time to time and from situation to situation. And so God's redemptive response changes accordingly.

From the outset I have to state that the popular distinction between ancestor veneration and ancestor worship is not helpful for my purposes, unless these concepts are more carefully defined. Family ancestors are not worshipped in traditional cultures. They are neither divine nor blameless. They maintain the characteristics and attitudes they had when alive. They can be scolded when they fail in their duties. They depend on the recognition of their descendents for their survival. Neglect of appropriate rituals makes them homeless and dangerous roaming spirits.

\footnotetext{
Klaus Nürnberger: The living dead and the living God: Christ and the ancestors in a changing Africa. Pietermaritzburg: Cluster Publications/Pretoria: CB Powell Bible Centre, Unisa, 2007.

"Ancestor Veneration in the Church of Christ?" JTSA No 129/Nov 2007 54-69.

See Nürnberger 2002(a) and 2004, the former also for relevant literature on the topic.
} 
On the other hand, they are not merely honoured. In a patriarchal culture the previous generation has authority over the subsequent generation while still alive. This authority is acknowledged and enhanced when the deceased are re-integrated into their rightful position in the lineage. This usually happens a year after their deaths. The most relevant ancestor is always the most proximate, the one that one knew and obeyed while alive.

It is not just a case of people honouring the memory of their dead. Their blessing is indispensable. Their traditions must be respected. Their precepts must be obeyed. Their anger is feared. When calamity strikes, they must be appeased and reconciled. For all intents and purposes they become the transcendent counterparts of the living. The issue in this treatise is not whether elders are loved and respected; the issue is whether the deceased have authority over the living. ${ }^{4}$ This is what I mean by ancestor veneration.

\section{The Importance of History for Israel}

The lives of predecessors always impact the lives of their successors even after they have relinquished their positions (Bediako 1991:224ff). In the Old Testament this is not only self-evident, but constitutive for the relationship between Yahweh and Israel. God had taken the initiative to establish a relationship with the prime ancestors of Israel, Abraham, Isaac and Jacob. He had formalised this relationship in the Sinaitic covenant. David and his dynasty were granted a covenant of their own as the designated leaders of Israel.

Yahweh's history with Israel constituted the 'confession of faith' of the Jews even in New Testament times (Acts 7). Faith in Christ too is rooted in the "story of Christ" - his incarnation in human reality, his ministry, his suffering and death, his appearances as the risen Lord, his presence among the community of believers in the Spirit. There is no Israelite, and no Christian faith without the story depicting God's 'great acts' in history (Schmidt 1983:84ff).

Yahweh had used human instruments in this history: the prime ancestors, Moses, Aaron, David, the prophets, priestly authorities, sages and so on. In New Testament times it was primarily Jesus, then the apostles, the early missionaries and those who compiled the books of the New Testament. Yet nowhere and never did these instruments of Yahweh possess any authority of their own, not even Christ himself (Jn 5:19). Yahweh and Yahweh alone was the covenant partner of Israel and this God manifested himself in Christ as the God of unconditional redeeming love. Apart from this manifestation of God in Christ we have no access to the biblical God. Not even the Mosaic Law can fulfil the role of Christ.

This is also true for the deceased. The possible existence and character of ancestor veneration in the popular religion of early Israel, which has elicited some debate recently, is not immediately relevant to the topic. ${ }^{5}$ The findings are mostly negative, or inconclusive at best. The evidence in favour is scarce and controversial. If it occurred at all, there is

For detail see Nürnberger op cit. 2007:21ff.

Here are a few revealing publications: K Spronk: Beatific afterlife in Ancient Israel and the Ancient Near East (Alter Orient und Altes Testament 219) Kevelaer: Butzon \& Bereker/Neukirchen-Vluyn: Neukirchener Verlag, 1986. This book has sparked a lively debate. Nadav Na'aman: Death formulae and burial place of the kings of the House of David. Biblica 85 (2004) 245ff. Brian B Schmidt: Israel's beneficent dead: Ancestor cult and necromancy in ancient Israelite religion and tradition. (Forschungen zum Alten Testament 11) Tübingen: Mohr (Siebeck) 1994. Kwesi Dickson has pioneered the debate from an African perspective, see e.g. Dickson, Kwesi A, \& P Ellingworth, (eds.) 1969. Biblical revelation and African beliefs. London, UK: Lutterworth/Maryknoll, NY: Orbis. A useful overview of African biblical scholarship is found in Mario I. Aguilar: Time, communion, and ancestry in African biblical interpretation: a contextual note on 1 Maccabees 2:49-70. Biblical Theology Bulletin - Fall, 2002.

http://findarticles.com/p/articles/mi_m0LAL/is_3_32/ai_94330697/pg _5 
virtually no trace left of it, whether in the Scriptures or in archaeological findings. ${ }^{6}$

The only overt case of a contact with a deceased person in the Old Testament was Saul's attempt to consult Samuel through the services of the witch of Endor in (1 Sam $28){ }^{7}$ Note that even this lone instance was not a case of ancestor veneration. Samuel was not an ancestor of Saul but a prophet of Yahweh. The text also makes it clear that the practice is off limits for an Israelite and led to no relief.

Although early Israelite family spirituality was not strictly monotheistic, ancestor veneration seemingly played no role. The little figurines that were found in excavations depicted family gods, not ancestors (Gerstenberger 2001, ch 5). These gods were supposed to guarantee fertility, not the male lineage. That popular Israelite religion was strongly impacted by its Canaanite counterpart is a well-known fact. A good example is the hill-top sanctuaries dedicated to Ba'al.

But such influences were attacked by prophets, priests and even some kings. If early Israelite families had taken over the practice from their Canaanite counterparts, it was certainly considered illicit by the 'official' stance. Therefore it can also not be used as an argument for its acceptability from a biblical point of view. Like other believers, African readers use the canonical text, not the historical conjectures of scholarly research.

This phenomenon is remarkable because Israel had a strong patriarchal family culture. Families were under the control of male family heads (Ex 21:2ff). Cursing or striking one's parents carried the death penalty. There are long genealogies both in the Old and the New Testament. Yet the deceased were considered to be dead. When an old man died, his bones were gathered to those of his fathers in the family grave, while his life continued in his descendants (Judg 2:10). As an individual he played no further role. ${ }^{8}$

Parents had a divinely ordained task when alive, but their deaths removed them from the scene (Turaki 1968:168). The Old Testament faith was exceptionally realistic concerning the finality of death. The metaphor of Sheol (= the place of the dead) indicated a lifeless 'place'. It was something like an extended underground cemetery. Once there, one could not see the sun, enjoy life, or praise Yahweh any more (Job 7:7-10; Ps 6:5; Sir 17:27f). There was nothing that resembles a "communion of saints" that is supposed to include the deceased. Forebears could do nothing for their offspring and their offspring could do nothing for their forebears. Except for memories and ongoing consequences of their lives, death was the end of all relationships. ${ }^{9}$

Nor were they considered to be particularly holy. In later times priests objected against the proximity of the royal tombs to the temple because corpses were considered unclean. ${ }^{10}$ More importantly, when Israel ran into trouble, it was believed that the sins of the forebears

6 For the archaeology of burial practices see EM Bloch-Smith: Judahite burial practices and beliefs about the dead. JSOT Supplement 123. Sheffield: JSOT 1992. I did not access this book.

7 For an interesting analysis see Pamela Tamarkin Reis: Eating the blood: Saul and the witch of Endor. Journal vor the Study of the Old Testament Vol 22/1997 3-23.

8 Ezekiel does not belong to the pre-exilic situation. The deep going discussion of Block is curiously ambivalent, acknowledging the accepted view that for Israel there was no life after death, yet leaving the possibility open that the metaphorical depictions of new life for dead bones pointed towards life after death. Daniel L Block: Beyond the grace: Ezekiel's vision of death and afterlife. Bulletin for Biblical Research 2/1992 113-141.

9 To me the analysis of Leila Leah Bronner (A Journey to Heaven: The Jewish Search for Life Beyond, http://bibleandjewishstudies.com/articles/afterlife.htm) seems to want to read into the text what modern believers so desperately want to find there. The title of the essay in itself indicates the inappropriateness of the quest because Sheol certainly was something entirely different from 'heaven'.

10 Nadav Na'aman: Death formulae and the burial place of the kings of the House of David. Biblia 85/2004 $245 \mathrm{ff}$. 
were visited upon their offspring. Under the impact of the deuteronomic theology of history, especially, they got a bad name as the origin of all the calamities that descended upon Israel (Judg 2:6-23; 2 Chron 29:6ff, 34:21ff; Neh 9:16ff; Jer 16:19; Ez 20:4ff; Am 2:4; Acts 7:51f). A prophet could exclaim in desperation "I am no better than my ancestors!" (1 Ki 19:4).

\section{Abraham, Isaac and Jacob}

Abraham, Isaac and Jacob were remembered because they were taken to be the 'pioneers' with whom Yahweh had entered into a binding relationship (for detail see Alt 1989:1ff; Schmidt 1983:10ff; Thomson 1992:119). They were three because three originally separate tribal traditions and were merged when a united nation constituted itself. The promise of blessing, progeny and land to Abraham and his offspring was deemed valid for his descendants hundreds of years later.

Abraham's own ancestors played no role. In fact, they were discredited by deuteronomistic history writers as those who had worshipped other gods beyond the great river (Josh 24:2). Abraham was explicitly told: "leave your country, your people and your father's household, and go to the land I will show you" (Gen 12:1).

Just ponder the symbolic significance of this. At the foundational beginning of Israelite history somebody was told to abandon the familiarity and security of his family structures and depend solely on the guidance of Yahweh, his God. This radical turn from the known to the unknown, from the past to the future, from where the fathers had been to where the descendants were going to be, is echoed in the exodus: Israel is told to leave a predictable situation behind and embark upon a precarious pilgrimage to a promised land. Israel's prophets are geared to the future (Koch 1983:1ff). Deutero-Isaiah tells the exiles in Babylon to turn from the past to what God was going to do next (Is 43:18f).

We are not surprised, therefore, that even the three prime ancestors were not feared, honoured, consulted, reconciled, or given sacrifices. On the contrary, making contact with the deceased, or with any other spirit for that matter, was forbidden. In the (rather harsh) Priestly tradition it even carried the death penalty. Accepting the deceased as religious counterparts would have been a slap in the face of Yahweh, who wanted a direct personal relationship with his chosen people (Nürnberger 2002(a):141ff).

So there is no ancestor veneration in the Old Testament. This does not imply, of course, that the deceased had turned into demons. This unfortunate conclusion of some missionaries was based on a decontextualised reading of 1 Cor 10:20. It only means that (a) they were sinful and mortal human beings like everybody else, (b) that death had taken them out of action and (c) that they were not to be in the way of the direct and immediate relationship that God wanted to enjoy with his people. Israel was to relate with the "living God", not with dead people or lifeless idols.

\section{Ancestry in the New Testament}

In the New Testament this trend became even more pronounced (Nürnberger 2004:79ff). The genealogical sequence between forebears and descendants lost its religious importance altogether. Jesus and Paul never married and had no children. What mattered was the Fatherhood of God. For Paul, the significance of Abraham lay in the fact that he was the father of faith, not in the fact that he was the biological ancestor of his progeny (Rom 4:16). In the Synoptic Gospels, John the Baptist said that God could make children of Abraham out of stones (Mt 3:9).

Genealogies were designed mainly to confirm the divine legitimacy of specific offices 
within Israel, such as the Davidic kingship or the Aaronitic priesthood. The genealogy does not channel the life force of the clan from forebears to descendants as in African traditionalism. The genealogies of Jesus found in the Gospels of Matthew and Luke have a theological agenda, namely to establish the credentials of Jesus as the expected Messiah. He was indeed the "son of David", who was the "son of Abraham", who again was the "son of God".

The title 'son of David' was frequently applied to Jesus in the Synoptic Gospels because the Jews expected the Messiah to emerge from the Davidic dynasty to which powerful prophetic promises had been made. It was the promise of God that counted, not the inherent authority of the lineage or the dynasty. Nowhere did 'son of David' imply that Jesus was dependent on his forebears rather than on God.

In fact, the assumption that Jesus was the offspring of David, thus subject to David, could be problematised where it had lost its roots in Yahweh's redemptive motivation (Mat 22:43ff). In the Gospel of John Jesus bluntly rejects the idea by saying that "before Abraham, I was" (8:58). The Letter to the Hebrews has a particularly revealing passage in this regard. It says that Christ was like Melchizedek, "the king of righteousness and peace, who has no father, mother, genealogy, beginning or end" (Heb 7:3).

In the Gospels Jesus calls God his Father and the Father of his disciples. According to the legends of the virgin birth in the introductory chapters of Matthew and Luke Jesus did not owe his true existence to an earthly progenitor but to an intervention of the Spirit of God. John's Gospel applies the motif of the virgin birth to all believers in Christ, apparently correcting a wrong biological interpretation of the 'virgin birth' (John 1:13; 3:5ff).

When his family demanded to speak to him, Jesus said that only those who were obedient to God were his family (Mt 12:46). The disciples were told not to call anybody father or lord (Mt 23:8f). Jesus would set a son against his father and a daughter-in-law against her mother-in-law (Mat 10:35ff; cf 10:21, 19:29). A potential disciple, who wanted to perform his filial duties of "burying his father" before following Christ, was told to let the dead bury their dead ( $\mathrm{Lk}$ 9:59f). This is an unheard-of affront to the genealogical principle. It should not be construed as a lack of respect for one's parents, which was a deadly $\sin$ in the Old Testament, but understood as a call to abandon genealogical claims that threaten to gain priority over Christ.

All these are incredibly harsh statements. They are not in line with culture, but stand against culture. But why that, if God is a God of love and responsibility towards others? Throughout the generations this exclusiveness, this undivided commitment to Yahweh and Christ, caused great agonies and conflicts, but it was always deemed to be essential for our well-being and salvation. What matters here is not an abstract Christological doctrine, but God's creative and redemptive intentions for us that manifested themselves in Christ and that should never be compromised by human loyalties that threaten to become absolute.

As far as the vitality of the deceased is concerned, the New Testament takes death as seriously as the Old Testament. People become human when earthly material is granted life (Gen 2:7) and people return to dust when life is taken from the organic material that makes up their body (Gen 3:19). They come to life and they die as human beings - body, soul and spirit. If God in his mercy would grant them a new life after their deaths, this gift would consist of a new body, soul and spirit.

There is a fundamental difference, therefore, between the biblical notion of resurrection from the dead, the Greek notion of the immortality of the soul, and the African notion of ancestral ascendancy. Resurrection implies death of the entire person; immortality of the soul implies the presence of a divine element in the person that cannot die; becoming an 
ancestor implies that the vitality of the person is lost but his/her belonging and authority are confirmed and enhanced.

\section{Should Ancestors Exercise Authority on a Personal Basis?}

As far as the authority of the deceased over the believers is concerned, the message of the Old and the New Testament is clear: nothing, absolutely nothing, should ever assume authority over God's people, or be given space to stand between God and his people. When God had made himself accessible in Christ, nothing could stand between Christ and his disciples.

God is present in Christ; Christ is present in his Spirit. No further mediation is needed. You can turn to God himself, the ultimate cosmic authority, every minute of your life, located anywhere in the universe, with any problem you may encounter in any dimension of life. This is typical of the biblical faith.

Parents had a mandate from God, just as the state had a mandate from God. Both were instruments of God's creative and redemptive activity in the world. They had to be obeyed by children who had not come of age. They had to be respected and loved, just as all other people had to be respected and loved. They had to be cared for in their old age. Those who despised or neglected them were under God's curse. Respect for elders has never been an issue in biblical times. But never could they claim to have any authority of their own. And death finally removed them from the scene.

\section{Could Ancestors exercise Institutional Authority?}

On a personal basis believers are supposed to be mature, free and responsible sons and daughters of God. They are to be subject to nobody but Christ, the great Servant (Gal 3:23$4: 7 ; 5: 1 ; 5: 13 ;$ Mk 10:41ff; Jn 13:12-17). While they care for their elderly and respect their forebears, they find their own way into the future in the power of God and in responsibility before God.

However, can ancestors perhaps be linked to the Christian concept of the 'office' of secular authorities? Ancestors have fulfilled the role of parents when they were alive. Authorised by their own ancestors, they have kept the community together, given moral guidance, demanded respect and responsibility, and safeguarded the social order. Their own function as ancestors is a continuation of that mandate beyond their deaths.

According to Rom 13:1-7 offices are established by God himself to overcome evil and further the good, whether they are Christian or not. In the Ancient Near East and in Africa the term 'secular authorities' not only includes living kings and emperors but also the transcendent "principalities and powers" that underpin their authority. In fact, all state authorities have a religious or ideological substructure.

Can "the ancestors" (as opposed to a particular deceased father, grandmother or maternal uncle) not be regarded as an 'office' in the sense that is used by God to keep order, contain evil and further the good? In such an eventuality the same criterion would have to be applied to the ancestors that is applied to earthly rulers. If they acted in their own authority and in their own interest, they would not be legitimate in terms of biblical assumptions. They would have to be selfless servants of their subordinates whose task it was to protect, support, liberate and empower their subjects.

In Psalm 82, God, the cosmic King, presides over a heavenly 'cabinet meeting', a convocation of the other gods, whom he has installed as regional governors to see to it that justice is done (v. 4). As it turns out, they have failed to do so (v. 2 and 5). In consequence the 'foundations of the earth are shaking' (v. 5c). The divine king deposes them and 
condemns them to death (v. 7), in the meantime suffering humanity cries to God asking him to take over direct rule over them (v. 8).

It is remarkable that the other gods are not deposed for metaphysical reasons, but solely because they fail to implement the redemptive intentions of God, in this case to secure justice for the weak and vulnerable. Of course, Israel itself was not placed under the rule of another god. The Israelites were the people of Yahweh himself and subject to nobody else.

A New Testament parallel to Ps 82 is found in Eph 1:20-23. Here it is Christ who has been enthroned as the cosmic King by God. Existing cosmic authorities (= the rulers and gods of antiquity) are not automatically deposed, but they are subjected to the criteria of his rule. This time the criteria are not justice according to the torah, but the self-giving service of Christ as expressed in the cross. As in Rom 13 and Ps 82, the question is not whether they are Christian, but whether they conform to the redemptive purposes of God in Christ.

Again Christians fall under God's direct rule through Christ. The task of the church (the Body of Christ) is to represent Christ (its Head) in the world and to make the purposes of God known to these (pagan) authorities (Eph 1:22b and 3:10). Those whom God has put into authority tend to grab power and do what they like with it. They fail to fulfil their mandate. Therefore the trend in the Bible goes towards the vision of a direct rule of Yahweh. He is the ultimate King and he is expected to take over control (Ps 82:8; 1 Cor 15:24; Rev 21:23f.).

Christian eschatology has always considered the state to be a provisional arrangement to keep order until the Lord comes. What has changed in the New Testament is not God's lordship but its content. It is now the crucified Christ who is the Lord. The coming King would be the One who had re-interpreted the God of Israel as a God of self-giving, suffering, redeeming, transforming love.

\section{Limitations of Time}

The apocalyptic world-view has come and gone, but the assumption of the provisional nature of authorities harbours two enduring insights. In the first place it makes it possible to scrutinise their legitimacy. In the second place it shows that their mandate is limited in terms of time.

If Paul's injunction in Rom 13 had no time limit, should Jewish Christians continue to placate the Egyptian Pharaohs who had oppressed their ancestors a millennium and a half earlier and who claimed to be immortal? Should they continue to be subject to the Davidic dynasty? Should they be haunted by the pagan oppressors of their forebears (the Assyrians, Babylonians, Persians, Hellenists)? After all, God had placed these authorities over them, had he not?

The idea is absurd. Only contemporary authorities have a divine mandate and should be respected as such. The same is true for the authority of ancestry as an office. Already the Old Testament considered it to be part of a past age and its perpetuation was explicitly forbidden. Today authority has emancipatory and democratic connotations. As history moves on, some institutions do outlive their usefulness. Why should ancestral authority belong to these?

In Jeremiah 35 we have the account of a strange sect, the Recabites. Their ancestor had commanded his descendants not to be involved in the cultural transition from a nomadic life to a settled agricultural life. They were never to build houses, never to sow seeds, never to plant vineyards, never to drink wine, which was the treasured fruit of the vineyard in ancient times. They were to remain nomads, live in tents and tend their flocks for ever after.

As a result their culture stagnated at an early stage of Israelite history. They were 
simply left behind. Jeremiah does not argue that the Israelites should follow the Recabites in obeying their ancestors, but rebukes them for not being committed to Yahweh, their God, as fiercely as the Recabites were to their ancestor. Of course the Israelites were supposed to go forward into the Promised Land.

When the Jews became fixated to the past, their religious tradition stagnated as well. The same is true for Christian traditions of various kinds. There is grace in the fact that the past is the past; that it can be left behind; that every day is the gift of a new beginning; that we can turn to the future; that we are liberated from an oppressive situation that haunts us, and also from our own failures, of which we are ashamed. As Eph 2:1-10 formulates it: "You were once ... but now ...".

This is also true for spiritual authority. Why should deceased instruments of God (especially prophets, apostles and saints) not be consulted? Why do we still read Jeremiah, Paul, Augustine, Thomas, Luther and Calvin, if the deceased were not allowed to speak to us? The answer is that their spiritual legacy can enlighten and strengthen us, but if they dry us into their past they make us incapable of facing the future.

In his agony Saul sought to speak to the deceased Samuel (1 Sam 28). But instead of opening up a new future for Saul, this encounter sucked him back into the past. Being dead, Samuel could only repeat the curse he pronounced when he was alive. If we yield to memory, the past can exercise an incredible power over us. Could Saul not have been forgiven, blessed and restored in his authority, if he had come to Yahweh himself in penitence and faith? This has happened countless times.

I sometimes asked my African students whether my father, who had never seen a computer in his life, would be able to help me with a computer problem. They always rejected the idea as ridiculous. So should I then stop using my computer, or should I not rather stop consulting my father about my computer?

So on the one hand, the deceased should be respected. Their witness can transmit the good news to us, their good example can inspire us, their wisdom can inform us. On the other hand they should not be allowed to dominate our behaviour, draw us back into their situations, their problems, their patterns behaviour, their frames of reference. They should not prevent us from finding our own way into the future.

Christians do not believe in deceased apostles or saints. They believe in the risen Christ, the Christ who is to come, the Christ that liberates us and empowers us, rather than enslaving us, the Christ that opens up the future for us, rather than throwing us into the prison of the past. That seems to be the core of the matter.

\section{The Personal Relationship between God and Human Beings}

Is there something intrinsic in the biblical faith that precludes the authority of spiritual powers other than Yahweh, or Christ? Indeed there is (Brueggemann 1997:413ff). The two most basic assumptions of the biblical witness are (a) that God is the ultimate Source and Destiny of reality as a whole and (b) that human beings are meant to live in a close personal relationship with this God. Where this relationship is disturbed it must be restored. Such a disturbance is the root of human predicaments and only its restoration can restore comprehensive human well-being.

In all its forms the relationship can only be kept intact if humans are in line with the righteousness of God. God's righteousness is understood as God's faithfulness to his people, which calls for the faithfulness of God's people to God. God's intentions can be summarised as protection and justice for the weak and vulnerable, and redeeming love for all people in whatever kind of need. The law of God consists of representative examples of 
justice and love, which represent basic prerequisites of human well-being.

Human well-being is in jeopardy when humans fall out of the intimate relation with God, that is, (a) when they fail to transcend experienced reality towards its ultimate Source and Destiny, absolutise parts of creation and relate to them as if they were divine, or (b) when they get out of step with the creative and redemptive will of their Creator in their earthly relationships.

\section{Intolerance of other Spiritual Authorities}

That is why the biblical faith does not tolerate the acknowledgement of spiritual authorities other than God himself. It does not matter how these authorities came to be established, what purpose they were meant to achieve, or how they are legitimated. They have no right to control human beings unless they are direct instruments of God's creative and redemptive purposes. This is true for other gods as much as for the deceased. Where the present existence of the deceased is acknowledged at all, as for instance in Hebrews 12:23, they are part of the great throng that is subject to God together with the living. ${ }^{11}$

Human authorities too must have derived their mandate from God, otherwise they are not legitimate. They must act as instruments of the creative and redemptive purposes of God. Whenever they begin to act on the strength of their own authority and in their own interest, humankind is in trouble. When humankind is in trouble God becomes perturbed and intolerant. God is 'jealous' for his people. It is the love of God that does not want human beings to be misled and abused.

Therefore Yahweh has no rivals and no cohorts. The Israelites were told that "I am Yahweh, your God, who brought you out of the land of Egypt, the house of slavery, you shall have no other gods before my face" (Deut 5:6f). The covenant between Yahweh and Israel is exclusive (Nürnberger 2002(a):295ff). Similarly Christ, God's representative on earth, does not share his lordship with other authorities.

Originally, this did not imply that there are no other gods, only that these gods have no authority over Israel, thus no claim on Israel's obedience. Later it was argued that these gods have been placed over the other nations by Yahweh himself as instruments of his justice, and that they were demoted because they were corrupt (Ps 82). Even later it was said that there are no such gods. The images made of wood or stone were nothing but wood and stone because the transcendent reality they were meant to symbolise did not exist (Jer 2:26-28; Is 44:9-20; Ez 20:32).

Thus fertility was not attributed to Ba'al but to Yahweh. The calamity of the exile was not attributed to Marduk, the god of Babylon, but to Yahweh, the God of Israel. The return was not attributed to Ahuramazda, the Persian god, but to Yahweh. Under the influence of Persian religion the Jewish transcendent universe became populated with good and evil forces. But these 'angels' and 'demons' were instruments of Yahweh's grace or wrath. Nowhere were they allowed to assume an independent authority, function or honour.

Similar observations can be made in the New Testament. In the Synoptic Gospels two kinds of spiritual beings are mentioned: the angels who serve him, and the demons who are hostile to him. When demons assume control over the living, Jesus drives them out. Paul assumes that other gods do not exist, that their images are idols, that pagans bring their offerings to demons, that one cannot partake of the table of the Lord (= the Lord's Supper) and of the table of demons at the same time (1 Cor 10:14-22).

11 1 Cor 15:29 presupposes resurrection and cannot be quoted as an example of the deceased having control over the living. 
The Deutero-Pauline letters claim that Christ is seated above all spiritual forces that govern the universe (Eph 1:20ff). Christ was God's instrument of creation at the beginning and he will be God's judge in the final judgment at the end (Col 1:15-20; cf Mat 25:31ff). Christ is the first and the last and the living (Rev 1:17-18). He claims our exclusive loyalty.

\section{Family Religion}

The exclusiveness of faith in Yahweh effectively eliminated ancestor veneration, oracles and divination in the biblical tradition. It can be argued, however, that in ancient Israel there was a fundamental difference between the spirituality of grass roots communities, especially the extended family, and the official religion of the state and the institutionalised cult (Gerstenberger $2001 \mathrm{ch} 4$ \& 7). Only the latter survived in the biblical Canon.

Grass roots spirituality was geared to the needs of the family, such as the health and fertility of family members, agricultural land and livestock, sufficient water resources, protection against pests, wild animals and raiders, harmony within the community, respect for elders, property rights, truthfulness and dependability, faithfulness of spouses and so on.

There is ample evidence, both biblical and archaeological, that families had their own 'gods'. Excavations have produced a host of little figures that were kept in the home. Family gods made no universal claims. They had very limited horizons, not reaching beyond the life world of the clan. They were not jealous of the gods of other families. One could rely on them, but they were not almighty.

They were like friendly chieftains who looked after the household. They were accessible. There was a very intimate relationship between family members and their god. They were very 'human', being characterised by love, faithfulness, trust, but also by anger at times when people did something foolish. They were geared to stability, tradition and authority, thus to the past. In short, they were the equivalents of the ancestors in African religion.

\section{Political Religion}

The official cult of the nation was an entirely different kind of phenomenon (Nürnberger 2002(a) ch 9\&10). In early times the Ark of the Covenant was a powerful symbol of unity. With the establishment of the united kingdom, a central sanctuary became important. David transferred the arch of the covenant and the Israelite priesthood to Jerusalem (2 Sam 6). Solomon built the temple (1 Ki 5-8). The rationale of the official cult in Jerusalem was to legitimate the authority of the king and to unite the people under his rule.

When the Davidic Empire split into the kingdoms of Northern Israel and Juda, Northerners re-established their own sanctuaries in Bethel and Dan and no longer went to Jerusalem. When the Northern kingdom was destroyed by the Assyrians this was widely seen to be the punishment of Yahweh.

It is in this situation that Deuteronomy was written. Its battle cry is the Sh'ma found in Dt 6:4ff: "Hear, o Israel, Yahweh is your God, Yahweh alone. You shall love Yahweh your God with all your heart, with all your soul and with all your might." No other loyalties or authorities were to be tolerated in Israel. Dt 18:9ff lumps together child sacrifice, divination, sorcery, interpretation of omens, witchcraft, casting of spells, being a medium or a spiritist, and consulting the deceased under the one great heading of pagan practices that are detestable to Yahweh. Israel was to fear no power, nor to use any power that was not the power given by Yahweh. No secret knowledge was to be sought. The knowledge of Yahweh's promise, as formulated in the covenant, and the knowledge of Yahweh's expectations, as formulated in the torah, were to be sufficient for life. 
When Assyrian domination declined, king Josiah of Judah tried to re-establish the Davidic kingdom. Deuteronomic theology served as the religious basis for the unification of the people under his rule. The people were no longer supposed to worship and bring sacrifices in their villages, nor at regional sanctuaries, but only in Jerusalem. Josiah enforced this principle ruthlessly. All Northern Israelite, Canaanite and syncretistic cults were liquidated. Local spiritual leaders lost their property, status and security. Israelite priests scattered in Judah were transferred to Jerusalem; those found in Northern Israel were executed. Local sanctuaries, altars and 'high places' were desecrated and demolished (2 Ki 23).

Since the time of Josiah local forms of worship, geared to local needs and conducted by family heads or local spiritual leaders, were suppressed. Worship of Yahweh implied regular pilgrimages to Jerusalem for fixed annual festivals. Sacrifices were conducted only by designated priests at the one designated place. Family altars were declared illegal as were ancient regional sanctuaries such as Bethel or Beersheba.

The emphasis of the institutionalised cult was placed firmly on obedience. Obedience to God translated into obedience to the king (Ps 2), to the priesthood, to the torah. The postexilic history writers pass judgement on the kings according to their loyalty to Yahweh and their obedience to the torah. The message was clear: apostasy and disobedience had led Israel into catastrophe and could only lead to further catastrophe (Wolff in Brueggemann \& Wolff 1982:85ff).

\section{Was Biblical Exclusiveness a Situational and Temporary Stance?}

One could argue, therefore, that the rigorous monotheism that emerged in the biblical faith was occasioned by political ambitions or necessities. State theology was designed to legitimate state authority. It had universal (rather than local) claims and aspirations. It formulated a clear-cut doctrine. It was intolerant of other beliefs. It removed God from immediate access. Only priests could mediate between God and commoners. It demanded strict obedience to fixed codes of conduct. All this may seem to be more than problematic.

Fact is, however, that the biblical faith as such remained fiercely monotheistic ever since. There must have been an intrinsic reason for that. After the Babylonians had put an end to the Davidic kingdom and the Romans had put an end to the sanctuary in Jerusalem, not only royal, but also priestly dominance came to an end. If monotheism had been a temporary phase in the history of Israel, it would have collapsed at this stage. But the personal and communal piety of Judaism as practised in local synagogues remained geared to Yahweh and Yahweh alone. The early church followed the model of the synagogue except that the risen Christ took the place of the torah as the focus of spirituality.

So, Israelite family religion cannot be considered to be canonical. This observation is important for our topic. The relaxed and pluralistic stance of Israelite 'family religion' is similar to African ancestor veneration. It is appealing to a post-modern culture. It creates space for all kinds of relationships to all kinds of spiritual beings. But such 'inclusiveness' seems to undermine the rationale of the biblical faith. What exactly is this rationale?

\section{Religious Imperialism?}

The exclusiveness of the biblical God can be condemned as an expression of religious presumptuousness and imperialistic designs. There is no doubt that more often than not Christianity has become guilty in this respect, but this has always been an aberration. Intolerance diametrically contradicts both the Israelite law and the Christian gospel.

The law is based on justice, the gospel on God's unconditional, redeeming, transforming acceptance in Christ, into which the Spirit of Christ wants to involve us. Tolerance 
and dialogue are built into the heart of the gospel message. In Christ, God has become a "Jew to the Jews". After the resurrection of Christ, he also became a Gentile to the Gentiles. And a true follower of Christ will join him in doing so (1 Cor 9:19-23).

But that does not mean that we should abandon the foundations of our faith. God invites us into his fellowship and claims our undivided loyalty precisely because he has a vision of comprehensive well-being for the whole of his creation. He wants to liberate us from parts of his creation that have turned into oppressive and life threatening powers and to empower us in Christ as his representatives on earth.

Certainly God can use other convictions for his creative and redemptive purposes and, according to the biblical witness, he has always done so. The biblical faith has absorbed and transformed religious elements from its Canaanite, Egyptian, Assyrian, Babylonian, Persian and Hellenistic environment (Schmid 1983:177ff). That has never been a problem. What the prophets castigated were injustice, idolatry, and a divided loyalty, not useful insights and revealing metaphors.

\section{Openness to other Faiths}

On this basis Christians are certainly entitled to, and capable of, entering into a constructive dialogue with other faiths without losing their spiritual bearings. Whatever is in line with the redemptive intentions of God, as manifest in Christ, is also acceptable from a Christian point of view. Christianity can learn from the insights of others and discover dimensions of their own faith that were obscure before. This has happened throughout the formation of the biblical witness.

To highlight the significance of Jesus for our relationship to God, for instance, the New Testament applied the royal and messianic titles found in the Jewish tradition to Jesus: Son of David, Son of God, Son of Man, the Annointed, the great Shepherd, and so on (Schmidt 1983:198ff). But the meaning of being a king changed from that of an oppressor (Psalm 2) to that of a servant (Mk 10:35-45; Jn 13:12-17 - Nürnberger 2004 ch 9; Theissen 1999:71ff).

One could certainly say in a pastoral context that Christ is our 'true ancestor', as opposed to our natural forebears. One just needs to be careful that the old patterns of thought do not slip in by the backdoor. This happened when Christ became the authoritarian king in heaven who conveniently legitimated an authoritarian emperor on earth when Christianity became the state religion of the Roman Empire. The Christian faith stands for freedom and responsibility, not for submissiveness and dependency. If Christ is an 'ancestor', he will have to be an ancestor of a very different kind.

One also needs to be careful that the use of metaphors taken from the environment does not create more confusion than clarity. This happened when the biblical message was translated into Hellenistic metaphysics and produced a host of contradictions. It may not be immediately clear to a normal African congregation why Christ should be called an ancestor. If it takes time to explain a metaphor that was supposed to bring greater clarity in the first place, one must be wary of potential misunderstanding.

So on the one hand the biblical faith is an open, flexible conviction that always responds to situational needs and their interpretations. On the other hand one has to take the biblical point of departure seriously. Faith in a God who has committed himself to the comprehensive well-being of every human being and the universe in all its aspects should never be undermined or diluted by dependence on spiritual authorities that stand for provisional, partial, private, or particularistic interests, let alone for oppression, exploitation and violence. 
The Source and Destiny of reality invites us into his liberating and empowering fellowship. Human beings are meant to share God's creative authority, redeeming love and comprehensive vision for his creation as a whole. To become acceptable from a Christian point of view other spiritual authorities have to demonstrate that this is what they stand for. "Acknowledgement of Yahweh requires re-ordering of everything else" (Brueggemann 1997:747-750). Of course, this criterion must be applied as ruthlessly to the Christian faith as to any other religious conviction. There have been and there are today versions of the Christian faith which stand condemned before the God of the biblical witness.

Obviously other convictions will also subject the Christian faith to critique on the basis of their own assumptions and are entitled to do so. We can only learn from such a critique. Only when we expose each other to our respective convictions can we grow in insight, appreciation of each other and co-operation with each other.

\section{BIBLIOGRAPHY}

Alt, A 1989 (1929). The God of the Fathers. In: Essays on Old Testament history and religion. Sheffield: JSOT Press.

Bediako, K 1991. Theology and identity. Oxford: Regnum.

Bediako, K 2004. Jesus and the gospel in Africa: History and experience. Maryknoll, NY: Orbis Books.

Brueggemann, W \& Wolff, HW 1982 (1975). The vitality of Old Testament traditions (2nd ed.). Atlanta: John Knox.

Brueggemann, W 1997. Theology of the Old Testament: Testimony, dispute, advocacy. Minneapolis: Fortress.

Gerstenberger, ES 2001. Theologies in the Old Testament, Minneapolis: Fortress Press and Edinburgh: T \& T Clark 2002

Herrmann, S 1981. A history of Israel in Old Testament times. Philadelphia: Fortress.

Koch, K 1983/4. The prophets. Vol I\&II. Philadelphia: Fortress.

Melanchthon, MJ 2005. Spirits: The biblical view. In: Wulfhorst, I (ed.). Ancestors, spirits and healing in Africa and Asia: A challenge to the church. Geneva: Lutheran World Federation.

Nürnberger, K 2002 (a). Theology of the Biblical Witness. Muenster (Germany): LIT-Verlag.

Nürnberger K, 2002 (b). The Spirit of God: Soteriological metaphor in biblical history and its significance for us today. Scriptura 79/2002 55-80.

Nürnberger K, 2004. Biblical Theology in outline: The vitality of the Word of God. Pietermaritzburg: Cluster Publications/Pretoria: CB Powell Bible Centre.

Nyamiti, Charles 1984. Christ as our ancestor: Christology from an African perspective. Gweru (Zimbabwe): Mambo Press.

Schmidt, WH 1983. The faith of the Old Testament: A history. Philadelphia: Westminster.

Theissen, G 1999. A theory of primitive Christian religion. London: SCM.

Thompson, TL 1992. Early history of the Israelite people: From the written and archaeological sources. Leiden: Brill.

Turaki, Y 1968. Christianity and African Gods. Potchefstroom: IRS. 